\title{
Rethinking the Bullet Theory in the Digital Age
}

\author{
Chinenye Nwabueze ${ }^{1 *}$, Ebere Okonkwo ${ }^{2}$ \\ ${ }^{1,2}$ Department of Mass Communication, Faculty of Social Sciences, Chukwuemeka Odumegwu Ojukwu \\ University, Igbariam Campus, Nigeria
}

*Corresponding Author: Chinenye Nwabueze, Department of Mass Communication, Faculty of Social Sciences, Chukwuemeka Odumegwu Ojukwu University, Igbariam Campus, Nigeria

\begin{abstract}
This study examined the relevance of the Magic Bullet theory also called the Hypodermic Needle theory in the digital age. It adopted the qualitative approach is exploring the following objectives examining the basic tenets of the Magic Bullet Theory, analyzing the arguments against the Magic Bullet theory, and examining the relevance of the Magic Bullet theory in the social media age. The analysis was premised on two key issues which were spread by the social media - the Monkey Pox Killer Vaccine incident of October 2017 and the Salt Water Bath incident of August 2014 during the Ebola Virus Outbreak that year. The study established that the Magic Bullet theory was still relevant today as the audience react in an 'actively passive' manner to certain media contents. The study found what could be described as the "Zombie Effect" reaction to specific media contents by audience in the digital age, supporting the credence of the magic bullet theory in the digital age. The study recommended further studies on bullet theory using other issues so as to further establish relevance of this theory in the digital age, contrary to postulations that the theory is no longer relevant in contemporary society.
\end{abstract}

\section{INTRODUCTION}

A theory is an explanation of how a phenomenon works or is likely to work. Theories are used to understand how things are likely to happen. A theory provides explanations for understanding a phenomenon. It is a tested and testable concept used to explain an occurrence (Nwabueze, 2014). A theory explains realities based on objective and sustained observation, it simply says why things happen in certain ways (Nwodu, 2006). This underscores the pertinence of theoretical perspectives to the explanation of patterns of behaviour or attitude within and among people (Nwabueze, 2014).

Communication theories are a collection theories are a collection of ideas used to explain, predict or understand the pattern, nature or outcome of communication process or activity. Mass communication theories, therefore explain or provide understanding of how the process of mass communication takes place in a setting or what the effects of mass communication process on the society could be (Nwabueze, 2014). Mass communication, mass media or communication-related theories are used to simplify understanding of the communication process, pattern, activity or effects on the audience and society. Put in another way, mass communication theories relate the communication process and activities to the society, the individuals, institutions, government and other elements of the society.

Mass communication theories come in different categories. One of such categories is Media Effects Theories. These are theories that explain how the mass media can influence people's attitude and behaviour, including how audience members are likely to react to mass media messages (Griffin, 2000; McQuail, 2010; Nwabueze, 2014). Among the media effects theories is the Bullet Theory also known as the Hypodermic Needle theory.

The bullet theory, magic bullet theory or hypodermic needle theory sees the mass media as having a direct, immediate and powerful effect on its audiences. Theory is one of the earliest theories in the field of mass communication. It basically says that an intended message is directly received and wholly accepted by the receiver. The theory is known by other names as well: Magic Bullet Theory, Transmission-Belt Model and Hypodermic-Syringe Model (Communication Studies, 2017).

Interestingly several theories have emerged to arguably caricature the substance of the bullet theory as an all powerful effect theory (McQuail, 2005). In the 1940s, Lazarsfeld disproved the "magic bullet" theory and "hypodermic needle model theory" through elections studies in "The People's Choice" and 
introduced the idea of the two-step flow of communication that same year (Griffin, 2000; McQuail, 2005). Other notable theories that emerged to counter the postulations of the magic bullet theory include the two step flow theory, as well as the uses and gratification theory seem to oppose the passive audience leaning of the bullet theory hence this analytical paper which seeks to revisit the substance of the bullet theory within the context of the social media occasioned by the advancement in the information and communication technologies.

However, the emergence of Information and Communication Technologies (ICTs) has changed the face of communication. These technologies have enhanced communication patterns and influenced outcomes in diverse ways. This means that early theories which existed prior to the emergence of ICTs and were disproved by some other theories, may require reassessment in the modern age to ascertain their relevance. It is against this backdrop that this study focuses on the magic bullet or hypodermic needle theory with a view to ascertaining its relevance in this social media age.

\subsection{Statement of Problem}

Information and Communication Technologies (ICTs) have changed the face of communication. The emergence of the New Media has provided the audience with diverse channels of information reception and assimilation. This is invariably comes with diverse influences on the audienc.

The "bullet theory" or "hypodermic needle theory" implied mass media had a direct, immediate and powerful effect on its audiences. The theory suggests that the mass media could influence a very large group of people directly and uniformly by 'shooting' or 'injecting' them with appropriate messages designed to trigger a desired response. However, several scholars led by Lazersfeld countered this theory as having a wrong impression of media effect on the audience. New assessments that the Magic Bullet Theory was not accurate came out of election studies in "The People's Choice," (Lazarsfeld, Berelson and Gaudet, 1944/1968). The opposing scholars opined that the media do not have an all powerful effect on the audience but that the audience had the power to make decisions on how to utilize media content (Griffin, 2000; McQuail, 2005).

However, with emerging trends in the digital age, especially the influence of the social media on the audience, there seems to be a possibility that magic bullet theory may have found relevance in the modern age. Whether this notion of fresh relevance of bullet theory is logically true is what this analytical work seeks to ascertain. This is in the light of recent incidents in Nigeria, one of which is the chaos that transpired in South Eastern states when people ran to primary and post-primary schools to withdraw their kids based on social media stories that the Nigerian Army was killing using Phantom Monkey Pox vaccination. This pandemonium began with social media reports of the alleged deaths in the schools. People did not pause to consider the truth behind the social media reports but rushed to schools to with draw their children, causing pandemonium. This created an impression that social media reports could be taken hook, line, and sinker by the audience and acted upon without considering the truth behind the facts. This was why the researcher decided to look at this issue in relation to the bullet theory which has been debunked by scholars

\subsection{Objectives of Study}

The basic objective of this study is to examine the relevance of Magic Bullet Theory in the Social Media age. Specifically, the seeks to;

- Examine the basic tenets of the Magic Bullet Theory.

- Analyze the arguments against the Magic Bullet theory.

- Examine the relevance of the Magic Bullet theory in the social media age.

\section{History OF THE BULlet THEORY}

The Bullet theory was propounded by Harold Lasswell after World War I. The theory emerged in the 1930s hence dominated thought on the quality and quantity of effect media messages do have on the target audience members (McQuail, 2005). As radio, movies and advertisements gained vast popularity between the 1930s and 1950s, the media's effects on people's behavior seemed all too apparent and, in some cases, extremely frightening (Communication Studies, 2017). Newspaper and magazine ads spurred on American consumerism, drawing even thrifty people into glittering department stores. President Franklin D. Roosevelt's radio speeches, known as the "fireside chats," 
inspired millions of citizens to support his New Deal policies in the wake of the Great Depression. Adolf Hitler used the media to spread Nazi propaganda in Germany, creating a unified force bent on conquering Europe (Communication Studies, 2017). To the common observer, people truly seemed powerless to resist the messages that came from the media. For the first time, messages were crafted with the target audience in mind to achieve specific responses.

During this time, behavioral scholars began to study the media's effects in earnest. Hypodermic Needle Theory was one of the first models to result from these early studies. However, the theory relied on traditional inductive reasoning with observation to support it, rather than modern deductive reasoning backed by methodical testing. Scholars were still trying to establish empirical methods for testing behavioral theories at the time.

In view of this therefore the substance of the bullet theory that the media messages do have direct and maximal influence on the target audience was used to analyze how media contents (propaganda) influenced the minds of the target audience in the second world war. According to Communication Theory (2017) during the Second World War media played a vital role in both United States and Germany at influencing the minds of the people. The theory was therefore used to glorify Germany's use of film and propaganda as well as United States use of films such as "it happened one night" and Mr. Smith goes to Washington" in the war time.

Despite its glorified substance, scholars have continued to describe the bullet theory as outdated and of no relevance in this technological age. One of such scholars is Paul Lazerfield and his two step flow theory. Paul Lazerfeld subjected the bullet theory to empirical test in 1940 using the USA presidential election as a reference point; and concluded that mass media contents do not have direct influence on the target audience but through the instrumentality of the opinion leaders. This finding has no doubt provided basis for other theories that emerged to caricature the substance of the bullet theory hence this study titled "rethinking the bullet theory in the digital era"

\subsection{Basic Tenets of the Bullet Theory}

The bullet theory or hypodermic needle theory postulates that the media (needle) injects the message into audience mind hence causes changes in audience behavior and psyche towards the message. This theory therefore refers to mass media audience members as passive and hence at the mercy of mass media contents. It therefore holds that persuasive media contents achieve the desired attitudinal change from the target audience (Griffin, 2000; McQuail, 2005).

Baran and Davis (2012) therefore note that in magic bullet theory "the rational mind is a mere façade, incapable of resisting powerful messages". In this instance therefore Lowey and Defleur (1995, p.4) explain the substance of the bullet theory thus:

$>$ Because people's actions are not influenced by social ties and are guided by uniform instincts, individuals attend to events (such as media messages) in similar ways.

$>$ People's inherited human nature and their isolated social condition lead them to receive and interpret media messages in a uniform way.

$>$ Thus media messages are like symbolic "bullets" striking every eye and resulting in effects on thought and behaviour that are direct, immediate, uniform and therefore powerful.

The bullet theory is therefore based on assumptions not on research findings; , it is therefore "based on assumption of human nature". This underscores why media scholars like Paul Lazarfield and Herta Herzog do not totally subscribe to the bullet theory even though they testified to the bullet theory in 1938 in a radio broadcast (the War of the Worlds) which gained wide spread reaction and panic among the American mass audience (Lowey and Defleur, 1995, p.4).

Several factors according to Communication Theory (2017) contributed to their strong effects of the mass media. They include:

$>$ The first rise and popularization of radio and television.

$>$ The emergence of the persuasion industries, such as advertising and propaganda.

$>$ The Payne Fund Studies of the 1930s which focuses on the impact of motion pictures on children 
$>$ Hitler's monopolization of the mass media during WW II to unify German public behind the Nazi party.

In summary therefore the bullet theory implies that mass media contents do have direct, immediate and powerful effect on its audiences. The Hypodermic Needle Theory promotes a few basic assumptions (Griffin, 2000; McQuail, 2005):

$>$ Humans react uniformly to stimuli.

$>$ The media's message is directly "injected" into the "bloodstream" of a population like fluid from a syringe.

$>$ Messages are strategically created to achieve desired responses.

$>$ The effects of the media's messages are immediate and powerful, capable of causing significant behavioral change in humans.

$>$ The public is powerless to escape the media's influence.

These assumptions prompted studies which led to opposing views and theories against the magic bullet theory and the all powerful effect of the media. The mass media of the time (that is 1930s, 1940s and 1950s) were perceived as very powerful hence influenced behavior. It therefore suffices that the mass media could influence a very large group of people directly and by shooting or injecting them with appropriate messages designed to trigger a desired response. Communication scholars beginning with Lazarsfeld came up with studies that countered the postulations of the bullet theory that saw mass media as having a passive audience. The opposing theories argued that the mass media had active audience. Let's look at opposing postulations against the bullet theory.

\subsection{Arguments against the Bullet Theory}

Several scholars emerged with theories debunking the magic bullet theory. One of the first studies that disproved Hypodermic Needle Theory was "The People's Choice," conducted by researchers Paul Lazarsfeld and Herta Herzog in the 1940s. The study analyzed the effects of media propaganda on people's voting decisions. Lazarsfeld and Herzog examined voting data during the 1940 election of Franklin D. Roosevelt and discovered that interpersonal sources of opinion influenced voters far more than the media did. In many cases, the media's propaganda had no effect on the public at all (Griffin, 2000; McQuail, 2005; Communication Studies, 2017).

The study proved that people could choose which messages to accept from the media, as well as determine the degree to which those messages would affect them. It found that people were not the helpless, passive victims of the media as Hypodermic Needle Theory suggested. From his research, Lazarsfeld, along with Elihu Katz, developed the two-step flow model of communication, stating that the media's messages are first received and interpreted by opinion leaders before they reach the general public (Griffin, 2000; McQuail, 2005; Communication Studies, 2017). Even the "Panic Broadcast" incident used to support Hypodermic Needle Theory was re-evaluated and declared to show diverse reactions among listeners (Communication Studies, 2017).

Although Hypodermic Needle Theory was instrumental in jump-starting communications research of mass media, it has since faded into obsolescence. With so many sources of information available today through a variety of media outlets, people have more control than ever over the messages that influence them. Many people now exercise selective exposure-seeking out only the information that supports their worldview. The argument is that though the media is still very influential today, its influence is far more complex and nuanced than in the early days of mass communication (Communication Studies, 2017). People can now interact with the media through social networking sites and can even direct the flow of information to others. Factors such as attitudes, beliefs, education and living situation determine whether a person will accept a message from the media. Still, in spite of the media's overwhelming presence in society, the biggest source of information and influence in a person's life continues to be interpersonal relationships (Nwabueze, 2014; Communication Studies, 2017).

Some other theories which presented opposing postulations against the bullet theory are the two-step flow theory, cognitive dissonance and uses and gratification theories. The cognitive dissonance theory, for instance, postulated by Leo Festinger in the 1950s assumes that an individual experiences 
a kind of psychological discomfort when exposed to logically incompatible information/ideas. As such he tries to reduce dissonance (discomfort) and achieve consonance (agreement) Smith (1998, p.630) therefore writes that an individual can reduce dissonance by (a) changing his attitude, changing the behavior and (c) modifying the perceived importance of the attitude or behaviour. Baran (2002, p. 380) emphasizes that "among the most important attitude change theories are the related ideas of dissonance and selective processes. The selective processes such as selective attention/ exposure, selective perception and selective retention therefore situate media audience members as active who actively decide and select what media content to expose themselves to and how to perceive such (believability) as well as what to retain in the memory. This is therefore unlike the bullet theory which positions the media audience as helpless in the face of media persuasive messages.

The Uses and Gratifications theory postulated in 1974 by Elihu Kalz, Jay Blumbler And Micheal Guveritch, according to Severin and Tankard (1997), is an audience centered approach which discusses how mass media users deliberately choose media contents that will satisfy given needs and allow one to enhance knowledge, relaxation, social interaction/ companionship, diversion or escape (McQuail, 2010). Unlike the bullet theory, the uses and gratification theory focuses on what people do with mass media contents, not otherwise. On this note therefore Richard and Turner (2007) identified the following among others as basic assumptions of the uses and gratification theory; i). The audience is active and its media use is goal oriented; ii). The initiative in linking need gratification to a specific media choice rests with the audience member; iii). The media competes with other sources for need satisfaction.

\section{The Digital Age in Perspective}

The role of traditional media has changed dramatically in the age of the internet-driven, 24-hour news cycle and the proliferation of social media. The definition of the traditional mass media (radio, television, newspapers and magazines) in the digital age has been expanded to include online and social media." Two key developments are; 1). The internet enables publication of massive usergenerated content, and (2). Social media enables one-to-one communication, as opposed to the one-tomany communication structure of traditional media.

Teenagers and young adults are the most active on social media and they happen to use it for almost everything involving their activities. Activities include going out, assignments, discussing their private lives, etc. Well at this time of the human stage, parents also join social networks to check on the activity of their children (Mahlangu, 2017).

Though the Internet and the World Wide Web created by Dr. Barnes-Lee 20 years ago (Embi and Hassan, 2012) are initially designed to move data and information from one location to another in a reliable and most efficient manner, the communication opportunities created by these major developments in information technology have taken on a whole new dimension. A major fallout of this development is the emergence of the social media which are social interaction channels which functionally involve both sender and receiver in determining message content. They are basically internet-based media such as Facebook, You Tube, Twitter, Wikis, Badoo and Myspace among others. These media involve people across the globe in a communication network where a message idea is introduced and the final message content determined by all after meaningful contributions.

Kaplan and Haenlein (2010) describe the social media as media that use web-based technologies to transform and broadcast media monologues into social media dialogues. The success and popularity of social networking sites show that the idea of online sharing has been successfully taken to the social and personal level (Embi and Hassan, 2012). This underscores the fact that social media emphasize dialogue, where active senders and active receivers play functional roles in shaping the message content. Amarasinghe (2010) suggest that online users engaging in social media interaction are generally motivated by similar factors which include: altruism, curiosity, sense of efficacy, pleasure of sharing, reciprocity, affiliation, power, collaboration, reward and recognition. Social network sites have become increasingly popular among youths and professional individuals. Research evidence has established that young adults spend time on the social media more than any other group. The observed popularity of internet use among young people and adults has impacted greatly on mass communication patterns in today's society (Kuss and Griffiths, 2011; Asogwa and Orji, 2013). 


\subsection{The Monkey Pox Killer Vaccine Rumour of October 2017: An Overview}

On the $11^{\text {th }}$ of October, 2017, pandemonium broke out in the South Eastern states of Nigeria that following rumour that Nigerian soldiers were in the states to inject children with vaccines as had allegedly been done in Bayelsa State with the hope of infecting them with the monkey pox disease. Several newspapers reported that the rumour had caused serious pandemonium as some people claimed that over 50 children had died in Nnewi after they were administered with the vaccines, leading parents to rush to the schools of their wards to withdraw them (Daily Post online, October, 11, 2017). Some others claimed the deaths were recorded in Abakaliki while some others said in Owerri or Enugu.

This pandemonium began with social media reports of the alleged deaths in the schools. People did not pause to consider the truth behind the social media reports but rushed to schools to with draw their children, causing pandemonium. This created an impression that social media reports could be taken hook, line, and sinker by the audience and acted upon without considering the truth behind the facts. This was why the researcher decided to look at this issue in relation to the bullet theory which has been debunked by scholars.

Several reports online (both social media and mainstream news platforms) contributed in causing the panic (see appendix). Among such reports are "Free Medical Outreach: Army Wanted to Depopulate Southeast Region With Monkey Pox - Residents Insist", (Onlinenigeria,com, October 12, 2017), "Parents Withdraw Children From Ondo State Schools Over False Rumors Of Deadly Vaccines", (Sahara Reporters, October 17, 2017); "Don't allow soldiers immunise your children - Ezeife tells Ndigbo". (Naij.com, Oct. 12, 2017); "Free medical outreach: Residents accuse army of plotting to depopulate South-East" (Punchonline, October 12, 2017). These reports gave the impression of tension and fear, further stirring the panic. WhatsApp messages were used immensely in passing across messages among friends to run to schools to pick up their children. Whether these messages were passed through the social media on mainstream media online, the point here is that the internet played a major role in spreading the information. The question then is why did people take the information the way it came without thinking before acting? This looks like the magic bullet theory in action, with the all powerful media effect that led to panic withdrawal of children from schools.

\subsection{The Salt Water Drink/Bath Incident (During Ebola Virus Outbreak) of August 2014}

Several persons were feared dead with many more hospitalised in various hospitals in Nigeria after consuming excessive quantity of salt and bitter kola to prevent Ebola Virus Disease (EVD) attack. This followed a viral message on social media which said that drinking or bathing with salt water could prevent the spread of the Ebola virus (Vanguard, August 8, 2014). The Federal Government had to go on air advising Nigerians to disregard the text message and postings on social media that hot water and salt may be used to prevent Ebola infection and cure infected persons.

\subsection{Magic Bullet Theory in the Digital Age: A Critical Appraisal}

No doubt advancement in the communication technologies has arguably redefined mass communication as well as its impact. The argument therefore that the bullet theory gained prominence when it was postulated because only few persons had access to television has also continued to gain popularity. This is specifically so in this age of social media. Interestingly, maximal access and use of social media platforms has resulted in increased exposure to western cultural programmes. This position obviously underscores the substance of the cultural imperialism theory of Herbert Schuller in 1976. This theory describes and explains the way "in which large multinational corporation including the media of developed countries dominated developing countries. It therefore suffices that the bullet theory provides vent for contemporary theories that hold relevance to the social media. The difference therefore between the 1930s and the contemporary digital age seems to be to the glory of the bullet theory. First, in the 1930s only few persons had access to television sets but in contemporary digital times countless people have access to television programme contents through their laptops, IPods and cell phones. It therefore suffices that many more ought to be influenced by the persuasive media contents.

It is argued today that the maximal access to the social media occasioned by the ICT's has eroded the substance of both the bullet and the two step flow theories. This is because a social relationship obviously exists among the internet users so much so that media influence no longer qualifies as 
direct (Funn, 1997). Apart from this, the position of the opinion leaders arguably no longer exist as people either react to media messages independently or in line with the internet social group norms and values. But what is seen today in response to some messages in the social media the proliferation of the social media, in certain instances, add to the powerful effect of the media which the bullet theory projects.

It stands therefore to reason that "as new technologies present people with more and more media choices, motivation and satisfaction become even more crucial components of audience analysis". Audience members are therefore motivated to provide satisfaction to their needs hence their choice of exposure to particular media contents in the social media. It therefore suffices that mass media audience members are active not passive; hence Rubin (1994) recognizes the potential for audience initiative and activity in the overall communication process. This is true, but in the digital age, the audience could be actively passive, as was the case in the Killer Monkey Pox incident where the audience were very active in responding to a false message but passive in making choices on whether the message was true or false.

In view of the different make up of audience members and their differing needs for gratification, different individuals tend to, as Levy and Windel (1984) observe display different types and amounts of activity in different communication settings and at different times in the communication process. But this was not the case in the Monkey Pox Killer Vaccine incident and the Salt Water bath incidents (during the time of Ebola Virus outbreak in Nigeria when in August 2014, the social media, particularly whatsApp spread false information that taking bath with salt water could prevent a person from contracting Ebola virus). Communication therefore is a process; and audience reaction to mass media contents qualifies as a process. It is a process of analyzing media contents in line with personal idiosyncrasies and expectations. Humans therefore are not robots to choicelessly react in a predetermined manner, according to arguments against the bullet theory. But the incidents considered in this work, debunk that argument, giving credence to the existence of the bullet theory in the digital age. Influence, according to Defleur and Ball-rokeach (1982) is determined by the interrelations between the media, it audience and society.

Man is therefore a product of his environment and is influenced by his environmental realities in his effort to change attitude. Media influence on attitude, according to arguments against the bullet theory, is not a "zombie" movement but a rational analysis of environmental situations and realities in search of gratifications. But the incidents of October 12, 2017 involving the hoax Killer Vaccine panic depict traits of a "zombie" media effect related to the magic bullet theory, conveyor-belt theory, hypodermic needle belt theory, one step flow theory, or the stimulus response theory. We take it further to say that specific issues determine what we call "zombie effect" reaction to media content which is similar to magic bullet theory. Much as the magic bullet may not be predominant today, there are facts showing that nature of an incident, including environmental factors of the audience lead to a "zombie effect" to media exposure which reflects the magic bullet theory. The Monkey Pox Killer Vaccine issue and the incident where many Nigerians took their bath with salt water as preventive measures to Ebola Virus are among cases that support the "zombie effect" reaction which occurs in the magic bullet format.

The social media therefore suggests an increased activeness of the media audience. This truism also derives from the reality of user generated content advantage of the social media. News is therefore not as unilaterally defined by the editor and passed as injections to the psyche of the audience members. News now are defined by citizen journalists with its characteristic demerits. Ideas are therefore cross fertilized in the social media as those defined by the bullet theory as audiences may well qualify as news breakers.

\section{CONCLUSION}

Deriving from the afore-discussed, the study concludes that the bullet theory still holds significance in the digital age since the audience members actively decide which social media platform to use and, depending on the nature of the story, passively react to contents they are exposed to. The bullet theory may not be predominant but should not be completely declared non-existent as the issued used in this studied showed. The social media has also widened the scope of human interaction and make for user generated contents and social presence. This adds to the powerful effect of the media, depending on the issue involved. 
Further studies on bullet theory are recommended here using other issues for the analysis. This is to further establish the relevance of the bullet theory in the digital age, especially with the advent of the social media.

\section{REFERENCES}

[1] Asogwa, C. \& Ojih, E. (2013). Social Networking Sites As Tools For Sexual Perversion Among Students Of University Of Nigeria, Nsukka. New Media and Mass Communication, Vol. 9: 27-38.

[2] Ball - Rokeah S.(1985). The origin of individual media system dependency: A sociological framework communication research 12.485 .

[3] Baran .S. (2012). Introduction to mass communication, media literacy and culture (second edition) New York McGraw Hill.

[4] Baran, S \& Davis, B. (2012). Mass media theory, (6the edition). New York. Wadsworth Centage.

[5] Communication Theory (2017), Accessed online November 8, 2017

[6] Defleur, M. \& Ball- Rokeach, S. (1982). Theories of mass communication (4 $4^{\text {th }}$ edition). New York: Longman.

[7] Finn, S. (1997). Origin of media exposure. Linking personality trait to TV,, radio, print and film use, Communication Research 24, 507-529.

[8] Granados, N. (2016). What is media in the Digital Age? Retireved 10-11-2017 from https://www.forbes.com/sites/nelsongranados/2016/10/03/what-is-media-in-the-digitalage/\#42b301e951ea

[9] Griffin, E. (2000). A first look at communication theory. Fourth edition. Boston: McGraw Hill.

[10] Lazarsfeld, P.F., Berelson, B. \& Gaudet, H. (1968). The people's choice: How the voter makes up his mind in a presidential campaign. New York: Columbia University Press.

[11] Levy, M. \& Windahi, S. (1984). Audience activity and gratifications. A conceptual clarification and exploration. Communication Research 11, 57-78

[12] McQuail (2010). McQuail mass communication theory ( Fifth Edition). London : Sage Publications.

[13] McQuail, D. (2005). McQuails mass communication theory, 5th edition. London: Sage Publications Limited.

[14] McQuail (1985). Mass communication theory: An introduction. Beverly Hills: Sage Publications.

[15] Nwodu, L.C (2004). Technological determinism theory and media practitioners' perception of cultural influence of ICTs on developing nations. The Nigerian journal of communications, (1(4) 72-83.

[16] Rubin, A. (1981). An examination of television reviewing motivations. Communication Research 8 141165

[17] Severein ,W \& Tankard (1997). Communication theories; origin, methods and uses in the mass media. New York: Longman.

[18] Smith, B. (1998). Psychology, science and understanding. USA: McGraw Hills Companies.

[19] Swanson D, (1977). Gratification seeking media exposure and audience interpretations. Journal of Broadcasting and Electronic Media 31,237-254.

[20] Communication Studies (2017). Hypodermic Needle Theory. Retrieved 10-11-2017 from http://www. communicationstudies.com/communication-theories/hypodermic-needle-theory.

[21] Mahlangu, T. R. (2017). The Social Media Age: Parents Following their Children on Social Media. Thrive global. Retrieved 10-11-2017 from https://www.thriveglobal.com/stories/15211-the-social-media-age

\section{APPENDIX}

Reports on the Monkey Pox Killer Vaccine Rumour

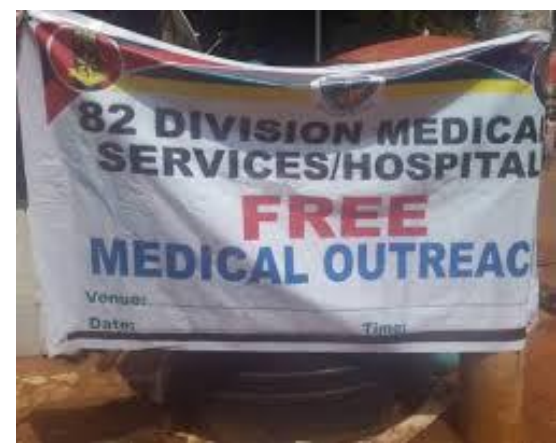

Banner showing the free medical services by the Nigerian Army 


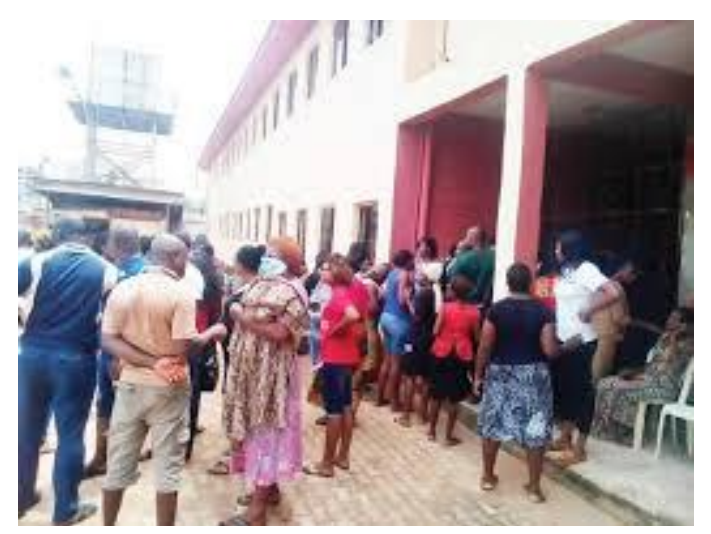

Parents waiting to pick their children from school due to the panic

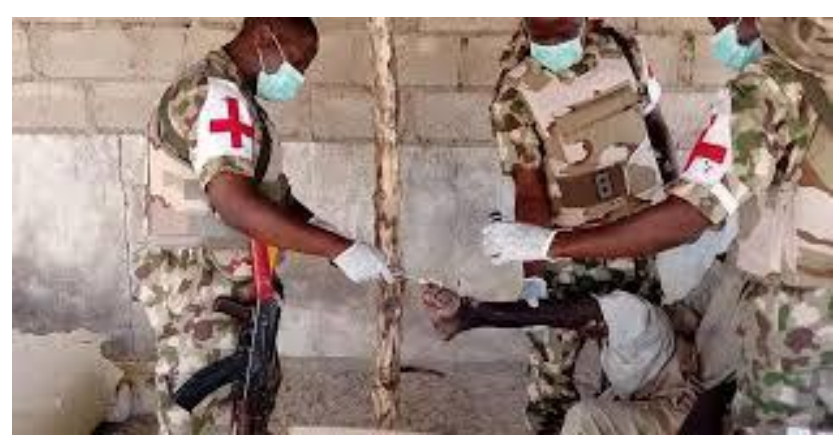

Army personnel giving the free medical service

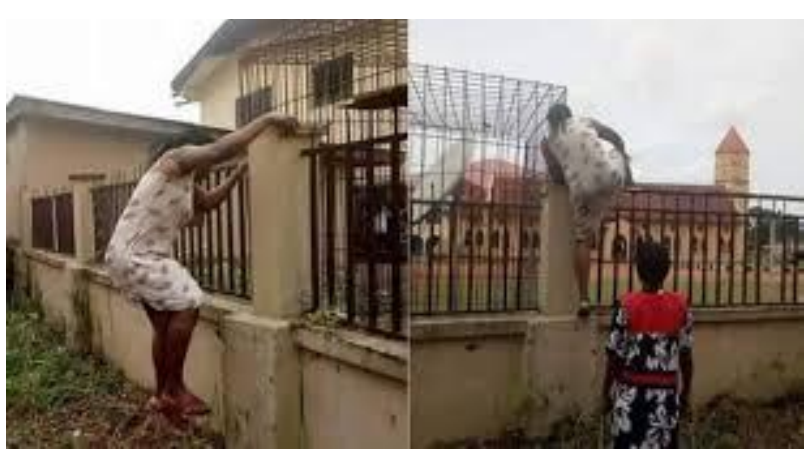

Some parents climbing fense to go and pick their children from school
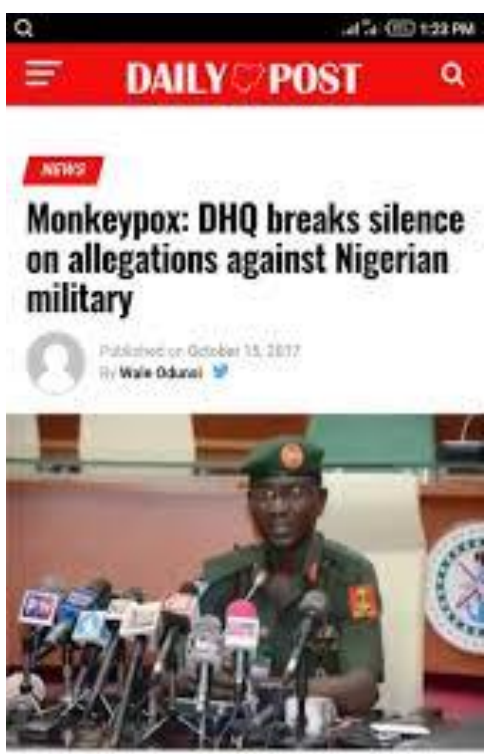

Nigeria's Defence Hechquaters (DHQP has urged Nigetians to disregard allegatiuns abost the

$$
\text { < } \equiv \text { 口 } 0
$$



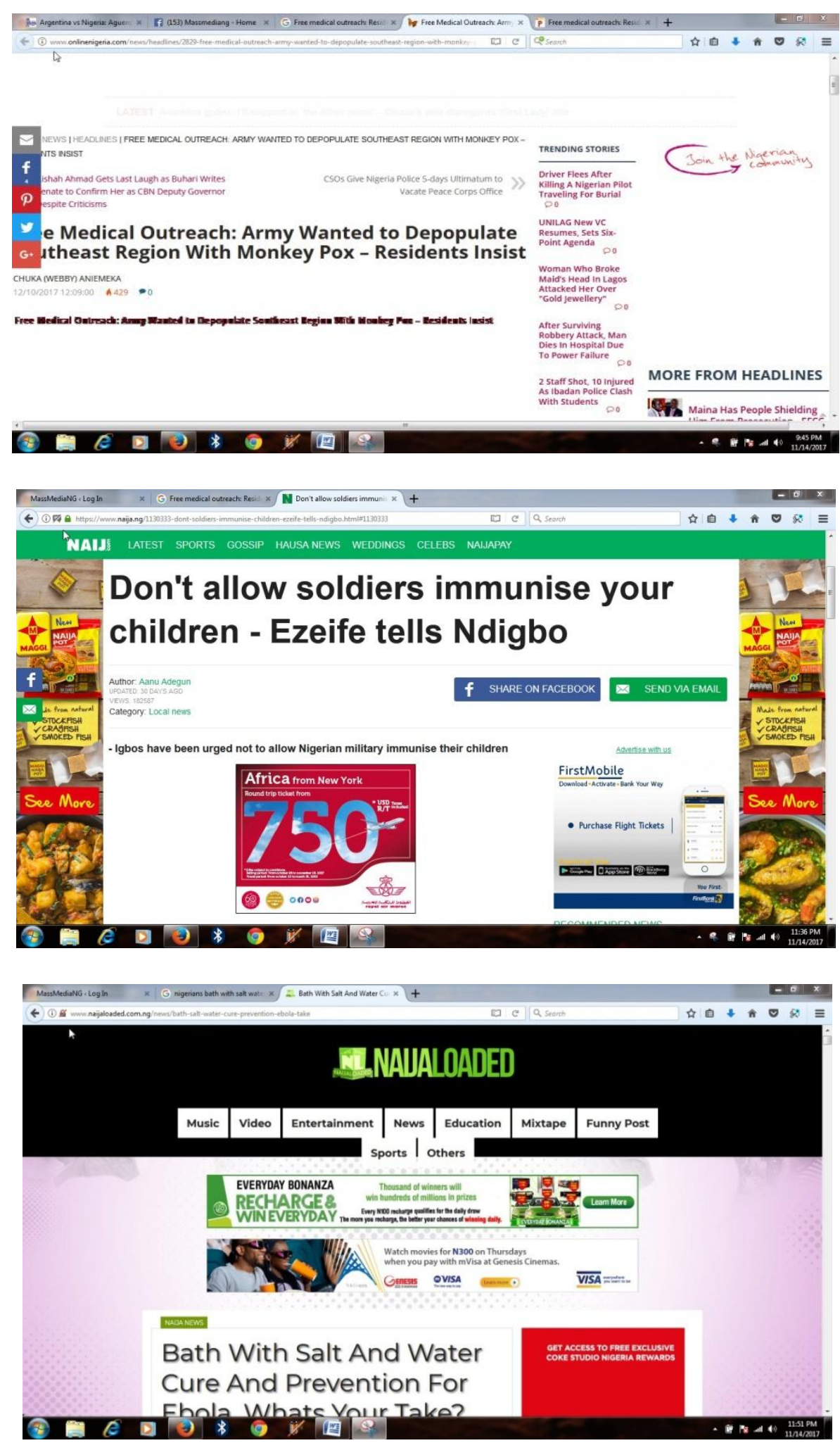

Citation: Chinenye Nwabueze, Ebere Okonkwo. "Rethinking the Bullet Theory in the Digital Age". International Journal of Media, Journalism and Mass Communications (IJMJMC), vol 4, no. 2, 2018, pp. 110. doi:http://dx.doi.org/10. 20431/2455-0043.0402001

Copyright: () 2018 Authors. This is an open-access article distributed under the terms of the Creative Commons Attribution License, which permits unrestricted use, distribution, and reproduction in any medium, provided the original author and source are credited. 